\title{
Promoting Student Autonomy and Competence Using a Hybrid Model for Teaching Physical Activity
}

\author{
Christine Bachman \\ Assoc. Prof., University of Houston Downtown, Houston, Texas, USA, \\ bachmanc@uhd.edu
}

\section{Rhonda Scherer}

Associate Director of Sports and Fitness, University of Houston Downtown, Houston, Texas, USA, schererr@uhd.edu

For approximately twenty-years, Web-enhanced learning environments have been popular in higher education. Much research has examined how best practices can integrate technology, pedagogical theories, and resources to enhance learning. Numerous studies of hybrid teaching have revealed mostly positive effects. Yet, very little research has examined how to teach a successful physical activity course using a hybrid format. Review of the literature: We reviewed the research regarding the design and implementation of a Web-enhanced physical activity course in a college population using pedagogical principles of learning and the self-determination theory. Method: Data were collected from students at the beginning and end of the course. The hybrid course consisted of completing weekly online activities, and selecting and participating in a face-to-face physical activity based on student's choice. Conclusion: The authors propose this template as a model to assist faculty in designing and implementing a blended physical activity course.

Keywords: Course design, web-enhanced course model, self-determination theory, students' perception, teaching

\section{INTRODUCTION}

Over the past two decades, the development of digital information technology and course management software has created many novel teaching and learning opportunities. One approach, the hybrid or blended approach, uses the benefits of online instruction in combination with face-to-face interaction. No prescriptive formula exists, as the two modes of instruction can easily be adapted to address different needs, courses and instruction styles. Dziuban and colleagues state that "ideally, blended learning is a pedagogically driven combination of resources and approaches, not a rigid percentage 
assignment to various instructions settings" (Dziuban et al., 2004). A recent metaanalysis has shown that hybrid courses result in superior student learning outcomes (Means et al., 2010). When properly implemented the hybrid format is generally more effective than either the face to face (FTF) or online format, as it increases student retention, decreases dropout rates (Estelami, 2012), meets the demand of non-traditional students, and allows them to plan online work around work and family responsibilities (Miller \& Lu, 2003). This mode of instruction has been extensively researched for many disciplines, but has not been applied to teaching college physical activity courses. Designing a physical activity hybrid course requires instructors to create "digital" and "live" activities that lead to self-centered learning, engagement and enjoyment. The purpose of this article is two-fold: 1) to provide a "best-practice" framework for designing and delivering a hybrid physical activity course, and 2) offer physical activity instructors with a theory based Web-enhanced model to enhance traditional teaching.

\section{REVIEW OF LITERATURE}

\section{The Traditional vs. Hybrid Classroom}

In a FTF classroom, instructors and students meet at a fixed time in a specific location. This approach has several benefits such as synchronous interaction, participation with classmates and instructor, and more importantly perhaps human contact. Conversely, online learning occurs in cyberspace whereby students can access resources and activities at anytime and from anywhere. One of the online teaching's main benefits is its ability to free education from the constraints of the FTF classroom and allowing students to complete the course at any time and from anywere. The term "hybrid" refers to the blending of these two teaching delivery modes by incorporating online and FTF elements using management software. Combining online with FTF activities facilitates the learning environment by allowing live interaction and increased flexibility for completing activities either FTF or online.

\section{Instructional Design and Best Practices}

McGee and Reis (2012) differentiates between "design" and "re-design" suggesting an important difference between modifying an existing course and designing a new course. Although it is easier to "design" a course, as fewer restrictions influence the designer, both designing and re-designing a course must consider best practices to effectively transform the FTF format into a successful hybrid delivery mode. Reigeluth (2013) emphasizes a design-oriented focus and techniques that promote learning. As such, course designers must integrate technological tools as vehicles to enhance instruction, and promote self-paced and self-directed learning, collaborative learning, customization, and autonomy with accountability.

\section{Technology and Strategies to Promote Learning}

\section{Self-Paced and Self-Directed Learning versus Collaborative Learning}

Self-paced and self-directed learning suggest that learners can independently control when, what and where they wish to study. Self-directed learning views learning as "active, energetic, free and aware [where the learner] chooses his goals, direction and 
behaviour [, and] is not ... pushed and pulled by his environment” (Tough, 1979, p. 45). In a hybrid environment, the learner is required to take control of his or her own learning, so designing online activities must foster students' cognitive responsibility and motivation. Self-directed teaching has mostly focused on "self-management of learning tasks" (Garrison, 1997, p. 20), and thus the focus is on teaching rather than learning. Garrison further adds that "critical thinking construct reflect[s] the complex cognitive processes associated with constructing personal meaning and worthwhile knowledge" (Garrison, 1997, p. 20). Creating meaningful experiences will move the learner to accept responsibility, and stimulate and contribute to students' own learning. In a hybrid course, self-paced content and corresponding activities can be tailored to get students to use and apply their own experiences to interpret and analyze the content with either online or FTF activities (Singh, 2003).

\section{Customizing Courses}

Customization of instruction strategies would either wrap the course around FTF or online activities. One approach would be to mix online resources to guide the learner and FTF activities to stimulate and motivate learning. For example, the instructor can focus on the flipped classroom model where the instructor delivers lectures online and involves students in FTF activities and discussions, or in the case of this study, FTF physical activities. Collaborative work can include various forms such as online versus classroom discussions, blogs, wikis or any other teamwork designed to get learners to share information and learn from each other.

\section{Promoting Accountability, Autonomy and Self-Directed Learning}

Behn (2001) posits that accountability equals expectations. As such, to hold students responsible for their work and performance, they must be able to link learning objectives to what the instructor expects of them. In a study of students' perceptions, Ward (2004) found that students' attitudes and sense of responsibility differed from FTF students such that students in hybrid courses were more likely to feel accountable for their work relative to traditional FTF students. Hensley (2005) proposes several strategies to enhance accountability while maintaining students' sense of autonomy. For example, designing a successful hybrid course should consider creating assignments to encourage students' critical thinking, allowing students to apply concepts and skills to real life situations and self-assess their learning, and very importantly, clearly specifying expectations for each assignment and activity.

Nowadays, almost everyone understands the importance of being physically active, regardless of age. Yet, the status of students' physical activity level is in serious trouble. In 2011, only $1 / 3$ of high school students had exercised for one hour over the week before the survey, and less than $1 / 2$ of adults participated in physical activity (Behn, 2001). Over the past few decades, not much has changed in higher education. In early 1980 s, Harris recognized that higher education had failed to accommodate and support physical activity instruction (p. 32). Today, physical activity is not often a curriculum requirement, and as such, students do not have many opportunities to learn the necessary skills and develop the motivation to exercise. 


\section{Self-Determination Theory, Motivation, and Physical Activity}

Self-determination theory (SDT), a theory of motivation, posits that all humans have an inherent need to be autonomous. Autonomous individuals feel free to initiate their own behaviour and can achieve congruence between the activity and their integrated sense of self (Deci \& Ryan, 2000). The need for autonomy reflects one's desire to feel intrinsic, and to self-organize experiences and behaviours, and thus, individuals tend to prefer activities that satisfy their autonomy. This is important because intrinsically motivated students do not need external incentives as the reward lies in the activity itself (Deci et al., 2001). Conversely, controlled behaviours are extrinsic and represent activities in which individuals feel pressured or coerced by internal or external forces, and thus do not reflect their true choice (Deci \& Ryan, 2000). Externally motivated students engage in activities for reasons separate from the activity itself, so they would exercise to improve their appearance or to avoid negative consequences such as failing a course. Often, college students have little choice when selecting their instructors, the day or the time of the day for their courses. Thus, one way to nurture their sense of autonomy and motivation would be to provide them with choices.

Past research has shown that autonomous supportive environments and offering choices significantly promoted students' levels of physical activity (How et al., 2013). Providing choices increases intrinsic motivation and thus offering physical activity choices may motivate students to be more active (Roemmich et al., 2012). Considerable evidence supports the idea that autonomy is vital. For example, giving instructions about what to do and how to do it without acknowledging students' preference leads to a decrease in motivation (Ryan \& Grolnick, 1986). Conversely, when teachers acknowledge students' perspectives and nurture their sense of choice, their intrinsic motivation for physical activity increases (Ntoumanis, 2005). Given that the need for autonomy includes one's inherent need to feel free when considering or performing an activity, environmental conditions must support individual choices, especially since exercise may not be inherently autonomous. Often individuals become physically active because they feel they have to. Much research has used a continuum to examine variations in motivation in predicting behaviour and wellbeing in several domains such as education, sport, health, and exercise (see Deci \& Ryan, 2000). Research has shown a positive relation between high levels of autonomy and participation in physical activity (Wilson et al., 2002; 2003). Autonomy-supportive social environments stimulate individuals to internalize and integrate behaviors, and become more intrinsically motivated (Deci \& Ryan, 2000). Intrinsic motivation is more likely to occur when individuals pursue activities they enjoy. Autonomy supportive environments also influence students' enjoyment and perceived competence (Liukkonen et al., 2010) and persistence. If individuals have fun and find the activity interesting and challenging, they feel more competent (Williams \& Deci, 1996) and thus are more likely to overcome obstacles (Thøgersen-Ntoumani, \& Ntoumanis, 2006). 


\section{Reasons for Designing a Hybrid PA Course}

Given the prevalence of physical inactivity among college students (McArthur \& Raedeke, 2009), increasing their physical activity is a priority. As students transition to their college life, they become more sedentary and their body mass index increases. Over one-third of college population is overweight or obese because of low levels of physical activity and poor health habits (West, 2012). A 2005 national survey indicates that six of 10 students participated in fewer than three days per week in vigorousintensity or moderate-intensity physical activity (American College of Sports Medicine, 2011). This is a concern especially in light of the evidence indicating that students who are physically active in college are more likely to maintain the same pattern over their lifespan (Sparling, 2007). It is thus critical to identify strategies that increase physical activity. Morrow and colleagues indicate that individuals understand the implications of being physically active, but do not know how to incorporate exercise in their lifestyle (Morrow et al., 2004). Further, they suggest the need to educate students, and provide information regarding the latest physical activities and exercise recommendations. Several initiatives, such as the healthy Campus 2010: Making It Happen (American College Health Association, 2002), promote physical activity courses and provide information necessary to maintain a healthy lifestyle. Many school districts offer online physical education due to shortage in physical education teachers (National Association for Sport and Physical Education "NASPE", 2007). However, online courses are plagued with high dropout or failure rate (Rostaminezhad et al., 2013), so NASPE considers the hybrid model to be a viable alternative for teaching physical activity.

\section{Course Structure}

The proposed course template was designed to be used by faculty members as a means to develop a theoretical, well organized physical education course (with the incorporation of physical activity) while utilizing Web enhanced tools and resources. Indeed, a model for teaching a hybrid physical activity course could very well encourage faculty to creatively use technology in course design. Course innovation that focuses on self-directed learning may also embolden current and future students to embrace exercise and learning about their health. Such a template also ensures that all instructors assigned to teach the course have access to a standard of curriculum delivery without having to start from scratch in developing course content. Providing a framework for instructors may facilitate and increase the delivery of hybrid physical activity courses.

One common dilemma in online courses is a student's lack of engagement. Given the increase number of students taking advantage of online courses, course design needs to consider factors that provide autonomy and optimum learner motivation. A well-planned hybrid course engages a student by offering meaningful and related assignments. It is important to allow students to feel both competent in the material being presented and connected to fellow classmates and instructor. As mentioned earlier, providing an autonomous environment will not only encourage their motivation but will enhance their intrinsic motivation. 


\section{Designing the Hybrid Course}

The self-determination theory and the Accredited Collegiate Sports Medicine's (ACSM) standard learning objectives for physical education guided content delivery and the development of assignments and assessments for this hybrid physical activity course. Our course development was based on past research that focused on adult education and lifelong learning and blending the traditional online and FTF activities. We found that using self-determination and ACSM guidelines contributed to the development of any hybrid course such that online activities promoted critical thinking and application of the content, provided information and resources, and in the case of this hybrid physical activity course, offered FTF physical activities that were both varied and engaging.

\section{Course Design and Student Autonomy and Motivation}

Our course design followed four goals: 1) to identify a textbook, 2) to develop learning outcomes that satisfied the requirements for a physical education course using various physical education curricula, 3) to offer lecture content that emphasized a self-paced learner and activities that promoted students' engagement, and 4) to help faculty members and students alike to be able to link the assignments with the textbook and learning outcomes.

To satisfy these goals, we first developed modules and learning outcomes based on our textbook. We created 1) online activities to replace the FTF activities that students did previously in the classroom, such as listening to a lecture, taking notes and completing tests, and 2) physical activities that included a variety of options for students to choose from and enjoy (Hijazi et al., 2006). All hybrid activities relating to content were offered online and were asynchronous, and thus provided students with autonomy over time and place for completing their assignments. To develop students' physical and academic skills, the course focused on strategies that facilitated students' learning about their health and increased their physical activity and their responsibility for their own learning. It was important to create an autonomy-supportive classroom that supported student autonomy and learning. Our desire to create a classroom to increase students' opportunities and choices led us to develop a curriculum that allowed students to take a variety of physical activity classes at varied times and locations.

The online activities included lectures, the completion of lab exercises, discussions and quizzes. The design of all online activities focused on increasing students' knowledge and ability to exercise independently. We created self-paced activities to enhance knowledge, autonomy, and skills that promoted students' healthy lifestyle by primarily scaffolding activities that students identified with and would benefit from. We carefully identified appropriate e-learning tools to promote autonomy outside the classroom and to avoid time pressure. Specific e-learning tools allowed students easy access to digital resources such as webinars and videos, and other useful tools like a heart rate monitor, how to keep with a healthy eating plan, and various educational health websites. Incorporating these e-learning tools in course activities stimulated adoption of lifelong health changes, and increased students' ability to understand their own health. 
In addition to the Web, this hybrid course used the e-learning platform Blackboard. Blackboard offers various tools that greatly facilitated an autonomous environment and student motivation. Organizing the course around discussions and blogs involved students' participation using an autonomous approach. As mentioned earlier, this is important, as motivation studies focusing on online learning have shown that generally online students are more intrinsically motivated than the FTF students suggesting that learner autonomy may play an important role in promoting student's motivation (Shroff \& Vogel, 2009; Xie et al., 2006).

A structural framework is important as it helps students to understand the demands of the course. Too often, instructors prefer structure and limited deadlines, as it is easier to present an organized and manageable course by restricting guidelines and offering strict deadlines. Yet, we made the decision to design a course that would allow students the freedom to make several choices. While this approach requires more course management, students' ability to complete the work on their own time was important. Consequently, we specifically designed the course template to create autonomy by creating flexible deadlines, and to allow students to choose among several physical activities.

Unlike most physical education courses which require students to select only one form of physical activity, the present course allowed the student to select from a large variety of physical activity options which were offered at various times during the day and during the week. According to self-determination, this option is superior especially because it emphasizes autonomy while at the same time offers the opportunity to share an activity with others. Requirements for the physical activity component required students to complete their FTF exercise by selecting and completing one of the fitness classes offered within the student recreation facility on campus. Students had the option to pick a physical activity from a variety of classes such as karate, aerobics, dance, Zumba ${ }^{\circledR}$, yoga, Pilates ${ }^{\circledR}$, step aerobics, breath and stretch, weight lifting or boot camp class. Based on our recommendation, the fitness center scheduled each physical activity course twice a week for one hour, and made sure that all courses were available at various times during the day and week. Nationally certified instructors within their respective field taught the physical activity classes and a qualified adjunct faculty member with credentials in Health \& Human Performance taught the online portion of course content. Though exercise instructors varied by age, gender and skill set, they each possessed a degree of motivational influence and the ability to lead a group class in exercise. Each class instructor maintained accountability for class participation by keeping a sign-in sheet. Additionally, students were able to swap physical activities at any time during the semester based on time offered, date offered, and preference of activity, skill level, or instructor. Students also completed an additional hour of physical activity on their own at their leisure or in one of the recreational classes, and reported their activity using the honor system.

As demonstrated in this article, our course template emphasized an autonomous environment. This approach to learning created opportunities for students to be physically active and learn on their own time. The asynchronous component encouraged 
a community of learners by engaging students to collaborate, reflect, share, and give feedback to classmates, answer discussions, and blog. Creating activities to engage students in both structured and unstructured discussions and activities gave students an opportunity to select a discussion among several topics to expound based on their personal experiences and interests. A grading rubric provided feedback, which allowed students to self-examine the quality of their own work and possibly their classmates' work. The rubric also helped faculty to apply grading standards to various discussion issues. We developed all discussion topics to create experiences in which students had to solve problems, make decisions, and explore various Web resources related to pertinent materials. Finally, students reflected on the significance of the material presented and shared their reflections with their classmates.

We conducted self-evaluations through weekly quizzes to provide students with opportunities to reflect on and critically examine what they had learned and adapted to their lifestyles. Breaking down the material in small chunks helped students to master the material and increase their sense of competence. Self-assessment opportunities provided regular feedback designed to increase subsequent testing which, according to self-determination principles, increase competence and intrinsic motivation (Deci \& Ryan, 1985).

\section{METHOD}

We developed a course template for teaching physical activity using a hybrid delivery format. The course was specifically designed to increase students' perception of autonomy. Our hypotheses were based on previous research of physical activity motivation (Wilson et al, 2004). We predicted that offering choices would increase students' autonomy, competence, enjoyment and level of physical activity over the course of the semester.

The University Internal Review Board approved this study. Participation was voluntary and students who agreed to participate in this study received course credit. All students enrolled in the physical activity course were invited to complete a pre- and post-survey that was designed to assess the variables. A total of 72 students (45\% male and 55\% female) from a non-residential, urban university in the southeast U.S. participated in this study. The percentages by ethnicity were similar to those in the university student population (37\% African American, 37\% Hispanic, 11\% White, and 15\% other).

\section{Procedure and Data Collection}

At the beginning of the semester, students first completed a demographic questionnaire, and a battery of questionnaires to assess their motivation, competence, and their level of physical activity. At the end of the semester, students completed the same battery of questionnaires and a 12-item survey relating to their enjoyment, and perception of the instructor and hybrid course.

\section{Measures:}

Relative Autonomy (RA) for Exercise. Students' regulation of exercise behaviour was assessed using an index of relative autonomy derived from the Behavioural Regulation 
in Exercise Questionnaire (BREQ: Markland \& Tobin, 2004). The measure examined motivation on a continuum using a 15 -item questionnaire on a Likert scale from 1 (not at all true) to 7 (very true). Questions followed a stem and asked students "Why do you exercise?" The answers measured external regulation (e.g., "I exercise because other people say I should"), introjected regulation (e.g., "I feel guilty when I don't exercise), identified regulation (e.g., "I value the benefits of exercise"), and intrinsic motivation (e.g., "I exercise because it's fun"). Autonomy scores were calculated into a single index known as the Relative Autonomy Index (RAI: Mullan et al., 1997). $\sum[($ external * -2) + (introjected $*-1)+($ identified $* 1)+($ intrinsic $* 2)]$. The RAI has been widely applied as it has the advantage to reduce the number of variables required to represent variations in regulation (Vallerand \& Ratelle, 2002).

The Motives for Physical Activity (MPAM-R: Ryan et al., 1997) measure included 30 items that assessed five motives for participating in physical activity. Only two were included and analysed: enjoyment and perceived competence. The interest/enjoyment subscale included 7 items such as (e.g., "Because it's fun; I find this activity stimulating"), and 7 items for competence ("Because I like engaging in activities which physically challenge me").

The Leisure Time Exercise Questions (LTEQ: Godin \& Shepard, 1985) assessed physical activity using three-items which asked participants to rate frequency of mild, moderate, and strenuous exercise they engaged in for at least 15 minutes per session over a typical week. A composite exercise behaviour score was then calculated using the weighted sum of each exercise intensity according to the following formula: (mild x 3$)+$ (moderate x 5) + (strenuous x 9). The result was a weekly MET (units of metabolic equivalence) value which represents the oxygen consumption at rest for physical activity of different intensities (Bouchard et al., 2007). Studies have shown the LTEQ to have adequate reliability and validity with respect to objective assessments of exercise behaviour and indices of fitness (e.g., Jacobs et al., 1993).

Students' Perceptions of the Course. At the end of the semester, students rated several items relating to their perceptions of the hybrid course. The survey consisted of three subscales: perceptions of 1) the course, 2) the instructor, and 3) course enjoyment. Questions included items such as I enjoyed the hybrid format of this course, I feel that being able to exercise on my own time is effective, and I feel that the labs were beneficial in supporting the lecture topics presented in this course.

\section{RESULTS}

Our goal was to develop and offer a template for teaching physical activity in a hybrid format and provide evidence for its effectiveness. All statistical analyses were carried out using the Statistical Methods for the Social Sciences (SPSS), Version 20. Data were screened to detect missing values, and normal distribution. Means and standard deviations were calculated for each variable for pre- and post-tests. Differences among ethnicities, age, and gender were assessed at baseline using independent t-tests. No difference was found for age and ethnicity, so we did not stratify the analyses. Significant differences were found for gender at the beginning of the semester, so 
analyses were conducted separately for males and females. ANOVA with repeated measures analyses were conducted to examine the variables.

Table 1 shows the means, standard deviations and reliabilities. When appropriate, independent sample t-tests were conducted to identify gender differences on each of the main variables. Analyses revealed significant gender differences for physical activity level and relative autonomy at the beginning of the semester and at the end of the semester. At the beginning of the semester, females relative to males reported significantly less physical activity, $t=2.87, \mathrm{df}=65, p<0.01$, and relative autonomy, $t$ $=, 3.08 \mathrm{df}=66, p<0.01$. At the end of the semester, no gender differences were found.

Table 1: Means, Standard Deviations and Cronbach $\alpha$

\begin{tabular}{|c|c|c|c|c|c|c|}
\hline \multirow[t]{2}{*}{ Variables } & \multirow{2}{*}{$\begin{array}{l}\text { Females } \\
\text { Pre-Test } 1 \\
\text { Means (SD) }\end{array}$} & \multirow{2}{*}{$\begin{array}{l}\text { Females } \\
\text { Pre-Test } 1 \\
\text { Means (SD) }\end{array}$} & \multirow{2}{*}{$\begin{array}{l}\text { Females } \\
\text { Pre-Test } 1 \\
\text { Means (SD) }\end{array}$} & \multirow{2}{*}{$\begin{array}{l}\text { Females } \\
\text { Pre-Test } 1 \\
\text { Means (SD) }\end{array}$} & \multicolumn{2}{|c|}{ Cronbach $\alpha$} \\
\hline & & & & & $\begin{array}{l}\text { Pre } \\
\text { Test }\end{array}$ & $\begin{array}{l}\text { Post } \\
\text { Test }\end{array}$ \\
\hline Relative Autonomy & $13.77(4.34)$ & $16.79(3.5)$ & $20.12(5.65)$ & $18.12(5.8)$ & & \\
\hline Perceived Competence & $4.79(1.27)$ & $5.52(1.51)$ & $5.28(1.23)$ & $5.42(1.11)$ & .98 & .93 \\
\hline $\begin{array}{ll}\text { Level of Physical } \\
\text { Activity }\end{array}$ & $\begin{array}{l}37.87 \\
(10.04) \\
\end{array}$ & $\begin{array}{l}30.73 \\
(11.61) \\
\end{array}$ & $\begin{array}{l}46.97 \\
(16.35) \\
\end{array}$ & $52.22(12.97)$ & & \\
\hline $\begin{array}{l}\text { Perception } \\
\text { Instructor }\end{array}$ & & & $4.45(1.19)$ & $4.43(.84)$ & & .97 \\
\hline $\begin{array}{l}\text { Perceptions of Hybrid } \\
\text { Course }\end{array}$ & & & $4.02(1.16)$ & $4.09(.80)$ & & .93 \\
\hline Student Enjoyment & & & $5.08(1.92)$ & $5.90(1.15)$ & & .97 \\
\hline
\end{tabular}

Zero order correlations are shown on Table 2. In line with self-determination theory, relative autonomy was positively correlated with perceived competence, physical activity, and perceptions of the instructor and hybrid course. Student enjoyment was positively correlated with their perceptions of the instructor and the course.

Table 2: Zero Order Correlations

\begin{tabular}{|c|c|c|c|c|c|c|}
\hline \multicolumn{2}{|c|}{ Variables } & 1 & 2 & 3 & 4 & 5 \\
\hline 1 & Relative Autonomy & 1 & & & & \\
\hline 2 & Perceived Competence & $.71 * *$ & 1 & & & \\
\hline 3 & Levels of Physical Activity & $.28 *$ & .28 & 1 & & \\
\hline 4 & Perception of Instructor & $.33 *$ & .Ns & Ns & 1 & \\
\hline 5 & Percept of Hybrid Course & $.34 *$ & $.34 *$ & Ns & $.85 * *$ & 1 \\
\hline 6 & Enjoyment & .30 & .26 & Ns & $.88 * *$ & $.88 * *$ \\
\hline
\end{tabular}

\section{Regression Analyses}

In separate regression analyses, we regressed relative autonomy on student perceptions of the hybrid course, perceived competence, enjoyment, and the amount of physical activity at the end of the semester. The first model was significant, $F(1,33)=4.08, p<$ .05 . Analyses revealed significant main effects of relative autonomy in predicting more positive perceptions of the hybrid course, $b=.34, t=2.02, p<.05$. The second model was significant, $F(1,33)=31.53, p<.001$. Analyses revealed significant main effects of relative autonomy in predicting increased levels of competence, $b=.71, t=5.63, p<$ .001 . The third model was also significant, $F(1,32)=32.24, p<.001$. Analyses revealed significant main effects of relative autonomy in predicting enjoyment, $b=.49, t$ 
$=3.17, p<.01$. The fourth model was also significant, $F(1,33)=4.07, p<.05$. Analyses revealed significant main effects of relative autonomy in predicting increased levels of physical activity, $b=.36, t=2.17, p<.05$. These findings support our hypotheses; that is higher levels of relative autonomy significantly predicted more positive perceptions of the hybrid course, greater competence and enjoyment, and greater levels of physical activity.

Finally, a one-way within subjects ANOVA was conducted to examine differences in relative levels of physical activity the beginning and the end of the semester. The results for the ANOVA indicated a significant time effects $F(1,39)=4.76, p<.05, \eta^{2}=.11$, suggesting that the format of the course encouraged students to become more physically active.

\section{CONCLUSION}

Recently, research has shown that self-determination is effective in exploring motivation in online contexts (Chen \& Jang, 2010; Harnett, 2010), but none has explored motivation in a hybrid physical activity classroom. Focusing on hybrid learning and motivation is key because higher levels of motivation help to buffer external constraints (Lepper et al., 2005). Given that autonomous regulation may increase when students can select a physical activity that is congruent with their sense of self, they may be more likely to be intrinsically motivated to engage and continue the activity. As such, creating a classroom that embraces autonomy is more likely to result in superior learning and to enhance students' feelings of competence and support. An autonomous environment also creates a sense of belonging as students feel like they can learn on their own time leading them to feel more competent and cared for. Moreover, students' perceptions of autonomy increases when they have choices and they can meet class requirements using flexible deadlines and physical activities they enjoy.

Our findings are consistent with past research. Providing choices and flexibility while maintaining high standards of learning promoted students' positive perceptions of the instructor and the course, and also enhanced their enjoyment. Our results demonstrate changes in relative autonomy and competence with regard to being physically active suggesting that the format of the course was in part responsible for these positive changes. Also, students' levels of physical activity increased over the course of the semester, especially for females. Moreover, students' course evaluations at the end of the semester clearly demonstrate positive perception of the instructor, the course and enjoyment of the course. It is thus reasonable to believe that the course format was responsible for students' changes in behaviours. One way to explain these is to examine instructor's feedback, organization and dedication to course design. We believe that focusing on increasing choices and flexibility allowed students to complete the course activities and be physically active. Several limitations should be noted. One limitation is due to the small sample size. Given that the course is an elective, few students complete the course every semester. Also, one way to strengthen the validity of the results would be to complete an experiment with one autonomous condition and one controlled condition. Finally, our students are non-traditional students; that is, in general they have family and work responsibilities and are commuters. 
Based on the literature, it is clear that most individuals understand the importance of being physically active, but in general, most individuals are not as physically active as is recommended (ACSM). In this article, we noted that higher education generally does not emphasize physical activity in their curricula. Yet, we also noted that the increase in sedentary behaviours and low levels of activity for a majority of college students must be addressed by creating an environment where physical activity takes a center role in teaching young adults ways to become physically active for life. Finally, research needs to focus on designing a variety of effective physical activity courses, including online and hybrid course that address the various factors that affect physical activity in young individuals.

\section{REFERENCES}

American College Health Association. (2002). Healthy Campus 2010: Making It Happen. The association. Retrieved from http://books.google.com/books/about/Healthy_Campus_2010.html?id=etu6HAAACAAJ

American College of Sports Medicine. (2011). ACSM issues new recommendations on quantity and quality of exercise. Retrieved from http://acsm.org/about-acsm/mediaroom/news-releases/2011/08/01/acsm-issues-new-recommendations-on-quantity-andquality-of-exercise.

Behn, R. D. (2001). Rethinking democratic accountability. Washington, DC: Brookings Institution Press Center for Disease Control. (2013). Physical Activity Facts. Retrieved from http://www.cdc.gov/healthyyouth/physicalactivity/facts.htm.

Bouchard et al. (2007). Physical activity and health. Champaign, IL: Human Kinetics.

Chen, K. C., \& Jang, S. J. (2010). Motivation in online learning: Testing a model of self-determination theory. Computers in Human Behavior, 26(4), 741-752. doi: 10.1016/j.chb10.1016/j.chb.2010.01.01.

Deci, E. L., \& Ryan, R. M. (1985). Intrinsic motivation and self-determination in human behaviour. New York: Plenum.

Deci, E. L., \& Ryan, R. M. (2000). The 'what' and 'why' of goal pursuits: Human needs and the self-determination of behavior. Psychological Inquiry, 11, 227-268.

Deci et al. (2001). Extrinsic rewards and intrinsic motivation in education: Reconsidered once again. Review of Educational Research, 71(1), 1-27.

Dziuban et al. (2004). "Blended Learning," ECAR, Research Bulletin 7. Retrieved from https://net.educause.edu/ir/library/pdf/ERB0407.pdf.

Estelami, H. (2012). An exploratory study of student satisfaction and learning outcomes in hybrid-online versus pure-online courses in marketing. Marketing Education Review, 22(2), 143-155.

Garrison, D. R. (1997). Self-directed learning: Toward a comprehensive model. Adult Education Quarterly, 48, 18-33. 
Godin, G., \& Shephard, R. J. (1985). A simple method to assess exercise behavior in the community. Canadian Journal of Applied Sports Science, 10, 141-146.

Harris, D. V. (1981). Physical activity: A house divided. The Academic Papers, 15, 3235 .

Hartnett, M. (2010). Motivation to learn in online environments: An exploration of two tertiary education contexts. Retrieved from http://muir.massey.ac.nz/handle/10179/2043.

Hensley, G. (2005). Creating a hybrid college course: Instructional design Notes and recommendations for beginners. Journal of Online Learning and Teaching. Retrieved from http://jolt.merlot.org/vol1_no2_hensley.

Hijazi et al., (2006). Maximizing learning by teaching blended courses. Proceedings of the 2006 ASCUE Conference, Myrtle Beach, S. C. Retrieved from http://faculty.ksu.edu.sa/mhabdelgawad/My\%20documents/blnded\%20learning.pdf.

How et al. (2013). The effects of choice on autonomous motivation, perceived autonomy support, and physical activity levels in high school education. Journal of Teaching in Physical Education, 32, 131-148.

Lepper et al., (2005). Intrinsic and extrinsic motivational orientations in the classroom: Age differences and academic correlates. Journal of Educational Psychology, 97(2), 184-196. doi: 10.1037/0022-0663.97.2.184.

Markland, D. A., \& Tobin, V. (2004). A modification to the behavioural regulation in exercise questionnaire to include an assessment of amotivation. Journal of Sport \& Exercise Psychology, 26, 191e-196.

McArthur, L. H., \& Raedeke, T. D. (2009). Race and sex difference in college student physical activity correlates. American Journal of Health Behaviours, 33, 80-90.

McGee, P., \& Reis, A. (2012). Blended course design: A synthesis of best practices. Journal of Asynchronous Learning Networks 16, 7-22.

Means et al., (2010). Evaluation of Evidence-based Practices in Online Learning: A Meta-analysis and Review of Online-learning Studies. US Department of Education, Office of Planning, Evaluation, and Policy Development, Policy and Program Studies Service: Washington, DC. Retrieved from http://www2.ed.gov/rschstat/eval/tech/evidence-based-practices/finalreport.pdf.

Miller, M., \& Lu, M. (2003). Serving non-traditional students in e-learning environments: Building successful communities in the virtual camps. Educational Media International, 40(1-2), 163-179.

Morrow et al., (2004). American adults' knowledge of exercise recommendations. Research Quarterly of Exercise and Sports, 75(3), 231-7.

Mullan et al. (1997). A graded conceptualization of self-determination in the regulation of exercise behaviour: development of a measure using confirmatory factor analytic 
procedures. Personality and Individual Differences, 23, 745-752. doi:10.1016/S01918869(97)00107-4

National Association for Sport and Physical education (NASPE). (2007). Position Statement: Initial physical education. Retrieved from http://www.shapeamerica.org/naspe/standards/upload/Initial-Guidelines-for-Online-PE2007.pdf.

Ntoumanis N. (2005). A prospective study of participation in optional school physical activity based on self-determination theory. Journal of Educational Psychology, 97, 444-453.

Reigeluth, C. M. (2013). Instructional-design theories and models: A new paradigm of instructional theory, Volume 2, edited by C. M. Reigeluth (pp. 5-30). New York, NY. Routledge Taylor \& Francis.

Roemmich et al. (2012). Autonomy supportive environments and mastery as basic factors to motivate physical activity in children: A controlled laboratory study. International Journal of Behavioural Nutrition and Physical Activity, 9(16). doi:10.1186/1479-5868-9-16

Rostaminezhad et al. (2013). Factors related to e-learner dropout, Case study of IUST elearning center. Procedia, Social and Behavioural Sciences, 83, 522-527.

Ryan, R. M., \& Grolnick, W. S. (1986). Origins and pawns in the classroom: Self-report and projective assessment of individual differences in children's perceptions. Journal of Personality and Social Psychology, 45, $736-7$.

Ryan et al. (1997). Intrinsic motivation and exercise adherence. International Journal of Sport Psychology, 28(4), 335-354.

Shroff, R. H., and Vogel, D. R. (2009). Assessing the factors deemed to support individual student intrinsic motivation in technology supported online and face-to-face discussions. Journal of Information Technology Education, 8, 59-85.

Sparling, P. B. (2007). Obesity on Campus. Preventing Chronic Disease. Public Health Research, Practice and Policy. Retrieved from http://ap.gatech.edu/Sparling/papers/Obesity\%20-\%20PCD\%202007.pdf

Thøgersen-Ntoumani, C., \& Ntoumanis, N. (2006). The role of self-determined motivation to the understanding of exercise-related behaviours, cognitions and physical self-evaluations. Journal of Sports Science, 24, 393-404.

Tough, A. M. (1979). The Adult's Learning Projects. A fresh approach to theory and practice in adult learning, Toronto: Ontario Institute for Studies in Education.

Vallerand, R. J., \& Ratelle, C. F. (2002). Intrinsic and extrinsic motivation: A hierarchical model. In E. L. Deci \& R. M. Ryan (Eds.), Handbook of self-determination research (pp. 37-63). Rochester, NY: The University of Rochester Press. 
Ward, B. (2004). The best of both worlds: A hybrid statistic Course. Journal of Statistics Education, 12(3). Retrieved from http://www.amstat.org/publications/jse/v12n3/ward.html.

West, C. D. (2012). Eating and physical activity habits of college students. Thesis; East Tennessee State University. $\quad$ Retrieved from www.http://honors.epub.etsu.edu/151/4/final thesis.

Williams, G. C, \& Deci, E. L. (1996). Internalization of biopsychosocial values by medical students. Journal of Personality and Social Psychology, 70, 767-779.

Wilson et al., (2002). Examining the psychometric properties of the behavioural regulation in exercise questionnaire. Measurement in Physical Education and Exercise Science, 6, 1-21.

Wilson et al., (2003). The relationships between psychological needs, self-determined motivation, exercise attitudes, and physical fitness. Journal of Applied Social Psychology, 33, 2373-2392.

Wilson et al., (2004). Relationships between exercise regulations and motivational consequences in university students. Research Quarterly Exercise and Sports. 75, 81-91.

Xie et al., (2006). Extending the traditional classroom through online discussion: The role of student motivation. Journal of Educational Computing Research, 34(1), 67-89.

\section{Turkish Abstract}

Beden Eğitimi Öğretiminde Hibrid Model Kullanarak Öğrenci Otonomisini ve Yeterliğini Geliştirme

Yaklaşık yirmi yıldır weble zenginleştirilmiş öğrenme ortamları yükseköğretimde popülerdir. Birçok araştırma öğretimi geliştirmek için teknolojiyi, pedagojik teorileri ve kaynakları en iyi şekilde bütünleştiren uygulamaları incelemiştir. Hibrid öğretmeyle ilgili birçok çalışma genellikle pozitif etkiler olduğunu ortaya çıkarmışıı. Fakat hibrid format kullanarak beden eğitimi dersini ögretme konusunda çok az çalışma yapılmıştır. Literatür taraması: Öğrenmenin pedagojik ilkeleri ve öz-belirleme teorisi kullanılarak yükseköğretim düzeyinde beden eğitimi dersinin tasarımı ve uygulamasıyla ilgili alanyazın taranmıştır. Yöntem: Veriler öğrencilerden dersin başında ve sonunda toplanmıştır. Hibrid ders haftalık çevrimiçi aktiviteleri tamamlama ve öğrencinin seçimine göre yüz yüze bir eğitimi içermektedir. Sonuç: Yazarlar bu modeli öğretim elemanlarına harmanlanmış bir beden eğitimi dersini tasarlamada ve uygulamada örnek olabilecek bir model olarak sunmaktadır.

Anahtar Kelimeler: Ders tasarlama, Weble zenginleştirilmiş ders modeli, öz-belirleme teorisi, öğrenci alg1s1, öğretim 


\section{French Abstract \\ Promotion d'Autonomie d'Étudiant et Compétence Utilisant un Modèle Hybride pour Enseigner Activité Physique}

Depuis environ vingt ans, l'utilization de l'autoformation educative a été vue positivement par les institutions de l'enseignment supérior. De nombreuses recherches ont examiné l'enseignment hybride et le protocole pour intégrer la technologie, les practiques pédagogiques, et les ressources afin d'améliorer l'enseignment. Ces études ont révélé des effets plutôt positifs, cepandant, très peu de recherches ont examine la façon d'enseigner un cours d'activité physique hybride. Revue de la littérature: Nous avons examiné la recherche des etudes hybrides pour concevoir et metre en œuvre un cours d'activité physique hybride. Notre article vise à etablir comment les etudiants s'approprient le dispositif hybrid de formation en autonomomie accompanée dans un cours d'activité physique. La théorie de l'auto-détermination est à la base de notre recherche et mise en place d'un moyen efficace de formation d'activité physique et de motivation. Méthode: Les reflexions des etudiants ont été recueillies au début et à la fin du cours. Le cours hybride etait composé de l'achèvement des activités hebdomadaires en ligne, et l'activité physique face-a-face basé sur le choix des étudiants. Conclusion: Les auteurs proposent un protocole ou modèle pour aider les professeurs a concevoir et metre en œuvre un cours d'activité physique hyride.

Mots-clés: Design de Cours, Modèle de Cours Amélioré de Web, Théorie d'Autodétermination, la Perception d'Étudiants, Enseignement

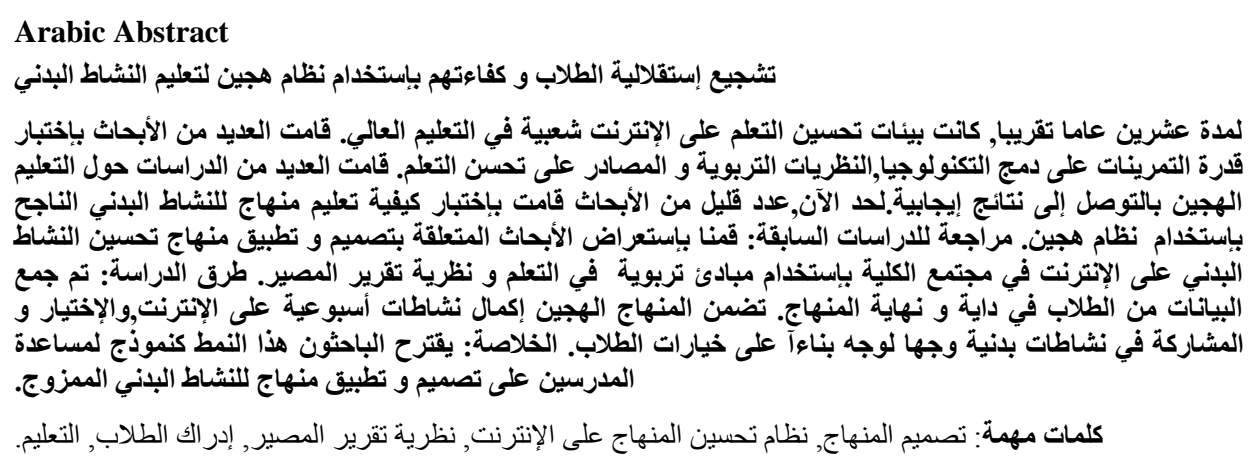

